\title{
Monocyte chemoattractant protein-1 is expressed in pancreatic islets from prediabetic NOD mice and in interleukin-1 $\beta$-exposed human and rat islet cells
}

\author{
M.-C.Chen ${ }^{1}$, P.Proost ${ }^{2}$, C. Gysemans ${ }^{3}$, C.Mathieu ${ }^{3}$, D. L. Eizirik ${ }^{1}$ \\ ${ }^{1}$ Gene Expression Unit, Diabetes Research Center, Vrije Universiteit Brussel, Brussels, Belgium \\ ${ }^{2}$ Laboratory of Molecular Immunology, Rega Institute for Medical Research, Catholic University Louvain, Louvain, Belgium \\ ${ }^{3}$ Laboratory for Experimental Medicine and Endocrinology (LEGENDO), Katholieke Universiteit Leuven, Leuven, Belgium
}

\section{Abstract}

Aims/hypothesis. Monocyte chemoattractant protein1 (MCP-1) attracts monocytes and T lymphocytes, and could thus contribute to mononuclear cell infiltration in Type I (insulin-dependent) diabetes mellitus. Cytokines induce MCP-1 mRNA expression in pancreatic rat beta cells. To investigate this issue, we analysed the signal transduction for IL- $1 \beta$-induced $\mathrm{MCP}-1$ expression in rat beta cells and in vitro MCP$1 \mathrm{mRNA}$ expression and protein release by human islets as well as in vivo islet MCP-1 mRNA expression in prediabetic non-obese diabetic mice.

Methods. Fluorescence-activated cell sorting-purified rat beta cells were cultured for $6 \mathrm{~h}$ with IL-1 $\beta$ (30 U/ $\mathrm{ml}$ ) or MAPK inhibitors or both. Human islets were cultured for $6-72 \mathrm{~h}$ with the cytokines IL- $1 \beta$, IFN- $\gamma$ or the inducible nitric oxide synthase (iNOS) inhibitor $N^{\mathrm{G}}$-methyl-L-arginine or both. We measured MCP-1 mRNA by RT-PCR and protein by ELISA. The MCP-1 mRNA expression in islets from male and female non-obese diabetic mice (2-12 weeks of age) was measured by real time reverse transcription-polymerase chain reaction (RT-PCR).
Results. Interleukin- $1 \beta$ induced MCP-1 mRNA expression in rat beta cells, with a maximum induction after $6 \mathrm{~h}$. A combination of p38 and ERK1/2 inhibitors decreased MCP- 1 expression by $70 \%$. IL- $1 \beta$ induced both MCP-1 mRNA expression and a threefold increase in medium MCP-1 protein accumulation in human islet cells. This effect was not prevented by iNOS blockers. In vivo there was an age-related increase in MCP-1 mRNA expression in islets from male and female non-obese diabetic mice, reaching a peak at 8 weeks.

Conclusion/interpretation. In rat and human islet cells MCP-1 mRNA is induced by IL- $1 \beta$. Both ERK1/2 and p38 MAPK, but not nitric oxide, contribute to MCP-1 expression. In non-obese diabetic mice MCP-1 mRNA expression increases with age, peaking at the early phases of insulitis. The production of MCP-1 by pancreatic beta cells could contribute to the recruitment of mononuclear cells into pancreatic islets in early Type I diabetes. [Diabetologia (2001) 44: 325-332]

Keywords Beta cell, MCP-1, interleukin-1, nitric oxide, diabetes mellitus, NOD mice, pancreatic islets, interferon- $\gamma$, human islets, polymerase chain reaction.
Received: 5 September 2000 and in revised form: 18 October 2000

Corresponding author: D.L. Eizirik, Gene Expression Unit, Diabetes Research Center, Vrije Universiteit Brussel, Laarbeeklaan 103, B-1090 Brussels, Belgium

Abbreviations: FACS, Fluorescence activated cell sorting; IL$1 \beta$, interleukin- $\beta$; ERK, extracellular signal-regulated kinase; iNOS, inducible nitric oxide synthase; MAPK, mitogen-activated protein kinase; MCP-1, monocyte chemoattractant protein-1; NO, nitric oxide; NOD, non-obese diabetic; RT-PCR, reverse transcription-polymerase chain reaction.
Type I (insulin-dependent) diabetes mellitus is an autoimmune disease characterized by the selective destruction of insulin-producing beta cells in the pancreatic islets of Langerhans [1]. This process is usually preceded by an inflammatory infiltration of mononuclear cells, containing predominantly monocytes and T lymphocytes, into the islet (insulitis) [2,3]. Chemotactic cytokines (or chemokines) play a crucial part in the recruitment of these immunocytes [4]. One of these chemokines is the monocyte chemoattractant protein-1 (MCP-1), a protein from the $\mathrm{C}-\mathrm{C}$ chemoki- 
ne subfamily. Monocyte chemoattractant protein-1 attracts monocytes and $\mathrm{T}$ lymphocytes and plays an important part in the local development of inflammation [5]. Thus, MCP-1 expression is increased at sites of inflammation in atherosclerosis, rheumatoid arthritis and glomerular diseases [6-11]. In animal models of glucan-induced pulmonary granulomatous vasculitis or cutaneous delayed-type hypersensitivityinduced inflammation, treatment with antibodies against MCP-1 prevents lymphocyte recruitment and disease outbreak [12, 13]. Moreover, transgenic mice expressing MCP-1 under control of the insulin promoter develop insulitis without diabetes [14], suggesting that this chemokine could be important in the recruitment of mononuclear cells into the islets in early diabetes.

One of the mechanisms by which invading mononuclear cells kill beta cells is by the local production of cytokines, such as interleukin- $1 \beta$ (IL- $1 \beta$ ) and interferon- $\gamma($ IFN- $\gamma)$ [15]. To characterize the molecular effects of IL- $1 \beta$ on rat beta cells we recently carried out a differential display of mRNA by RT-PCR (DD-RTPCR) [16]. Among the observed IL- $1 \beta$-induced genes, we detected increased expression of MCP-1, raising the possibility that the beta cells themselves are an important source of MCP-1 production in the early stage of insulitis. It was not, however, clear whether MCP-1 was also present in human pancreatic islets or in islets isolated from prediabetic NOD mice. Furthermore, there was no information on the signal transduction leading to IL- $1 \beta$-induced MCP-1 expression in rat beta cells.

In the present study we investigated the role of MAP kinases in IL- $1 \beta$-induced MCP- 1 mRNA expression in rat beta cells and the in vitro MCP-1 mRNA expression and protein release by human islets as well as the in vivo MCP-1 mRNA expression in prediabetic NOD mice.

\section{Materials and methods}

Islet cell preparation, culture and exposure to cytokines. Rat pancreatic islets were isolated from 10-week-old male Wistar rats by collagenase digestion and islet beta cells were purified by autofluorescence-activated cell sorting (FACStar, Beckton-Dickinson, Sunnyvale, Calif., USA) [17]. The beta cells were precultured overnight at $37^{\circ} \mathrm{C}$ in Ham's F-10 medium (GIBCO BRL-Life Technologies, Paisley, Scotland) supplemented with $5 \mathrm{mg} / \mathrm{ml}$ charcoal-treated BSA (fraction V, RIA grade, Sigma Chemicals, St. Louis, Mo., USA), $0.1 \mathrm{mg} / \mathrm{ml}$ streptomycin, $12.5 \mathrm{U} / \mathrm{ml}$ penicillin, $0.3 \mathrm{mg} / \mathrm{ml} \mathrm{L}$-glutamine and $10 \mathrm{mmol} / \mathrm{l}$ glucose. This was followed by overnight culture at $37^{\circ} \mathrm{C}$ in the same medium but with addition of $50 \mu \mathrm{mol} / \mathrm{l} 3$ isobutyl-l-methylxanthine (IBMX; Jansen Chimica, Beerse, Belgium), which is required to preserve beta-cell viability over prolonged periods in culture [18]. Rat beta cells $\left(10^{5}\right.$ cells $)$ were then exposed to recombinant human IL- $\beta(30 \mathrm{U} / \mathrm{ml}$, kindly provided by Dr. C. W. Reynolds, National Cancer Institute, Bethesda, USA), alone or together with the p38 inhibitor
SB203580 (p38i; $10 \mu \mathrm{M}$ ) from Calbiochem (La Jolla, Calif., USA) or the MAPK/ERK inhibitor PD098059 (MEKi; $100 \mu \mathrm{mol} / \mathrm{l}$ ) from New England Biolabs (Hitchin Hertfordshire, UK) [19-22]. Both p38i and MEKi were dissolved in dimethylsulphoxide (DMSO) $(0.14 \%, \mathrm{v} / \mathrm{v})$ and added $1 \mathrm{~h}$ before a $6 \mathrm{~h}$ exposure to IL- $1 \beta$. The doses selected for $\mathrm{p} 38 \mathrm{i}$ and MEKi have been shown to prevent IL- $1 \beta$-induced p38 and MEK activity in rat islets or beta cells, without affecting betacell function or viability $[22,23]$. The use of DMSO $(0.14 \%)$ as control condition does not affect beta-cell function [23]. We evaluated MCP-1 mRNA expression in the different culture conditions by RT-PCR (see below).

Human islet cells were isolated from pancreases obtained from 5 adult heart-beating organ donors. The organs were procured by European hospitals affiliated with the Eurotransplant Foundation (Leiden, The Netherlands) and with $\beta$ Cell Transplant, a multicentre programme on beta-cell transplantation in diabetes. They were processed at the Central Unit in Brussels as described previously [24, 25]. The mean donor age ( \pm SEM) was $21 \pm 6$ years (range $8-36$ years). Collagenase digests were separated by Ficoll gradient purification into an islet fraction. Isolated islets were cultured for 4-20 days in Ham's F10 containing 1\% BSA (Boehringer Mannheim, Mannheim, Germany), $7.5 \mathrm{mmol} / \mathrm{l}$ glucose, $0.075 \mathrm{mg} / \mathrm{ml}$ penicillin and $0.1 \mathrm{mg} / \mathrm{ml}$ streptomycin [26]. After culture, the islet preparations contained $70 \pm 2 \%$ beta cells and $15 \%$ alpha cells as determined by immunocytochemistry and electron microscopy $[17,25]$. To characterize the effects of cytokines on MCP-1 mRNA expression, human islet cells $\left(10^{5}\right.$ cells $)$ were exposed for 6 or $24 \mathrm{~h}$ to recombinant human IL-1 $\beta(50 \mathrm{U} / \mathrm{ml})$ or recombinant human IFN- $\gamma$ or both $(1000 \mathrm{U} / \mathrm{ml}$, Genzyme, Cambridge, Mass., USA) with or without $1.0 \mathrm{mmol} / \mathrm{l}$ of the iNOS inhibitor $N^{\mathrm{G}}$-methyl-L-arginine (L-MA, $1.0 \mathrm{mmol} / \mathrm{l}$; Sigma Chemicals). In some experiments the cells were also exposed to recombinant murine TNF- $\alpha(1000 \mathrm{U} / \mathrm{ml}$, Innogenetics, Belgium). The choice of cytokine and inhibitor agent concentrations was based on our previous data on insulin-producing cells and pancreatic islets, having as biological end point stimulation (cytokines) or inhibition (L-MA) of cytokine-induced iNOS expression or medium nitrite accumulation or both [16, 27-29].

NOD mouse experiments. Non-obese diabetic (NOD) mice inbred in our animal facility (Proefdierencentrum Leuven, Belgium) since 1990 were used as spontaneously diabetes-prone animals [30]. In our NOD mouse colony, insulitis appears around 4 weeks of age, reaching an incidence of $80 \%$ at 70 days of age and $100 \%$ at 200 days of age in both male and female mice $[31,32]$. Diabetes incidence at the time of the study was $72 \%$ in female and $23 \%$ in male mice around the age of 200 days. Mice were tested for glucosuria three times a week (Clinistix, Bayer Diagnostics, Tarrytown, N. Y., USA). At the end of the experiment, blood glucose was measured in tail vein blood using a Glucocard glucometer (Menarini, Florence, Italy). We used BALB/c mice (Harlan CBP, Zeist, The Netherlands) as non-diabetes-prone control. Pancreatic islets were isolated from 2, 4, 6, 8, 10 and 12-week-old male and female NOD mice, as well as from 4-week-old BALB/c mice, by collagenase digestion in cold Hank's salt solution and were handpicked under a stereomicroscope as described previously [33]. For histological analysis, pancreatic glands from all experimental NOD mice were snap-frozen in 2-methyl-butane $99 \%$ (ACROS Organics, Geel, Belgium) chilled in liquid nitrogen and 5- $\mu \mathrm{m}$ cryostat sections were stained with Mayers haematoxylin and eosin $(\mathrm{H} \& \mathrm{E})$ for evaluation of infiltrating immune cells by light microscopy [34-36]. A mean of 20 or more islets for each pancreas were scored for insulitis in a blinded manner. 
The level of lymphocytic infiltration in the islets was scored as follows: 0) no lymphocyte infiltration in or around the islets; 1) peri-ductular infiltrate; 2) peri-islet infiltrate; 3 ) intra-islet infiltrate; and 4) intra-islet invasion with beta-cell destruction.

Analysis of $m R N A$ expression. We isolated Poly (A) ${ }^{+}$RNA from rat and human cell aggregates $\left(5 \times 10^{4}-10^{5}\right.$ cells $)$ using oligo $(\mathrm{dT})_{25}$-coated polystyrene Dynabeads (DYNAL, Oslo, Norway). We prepared cDNA with the GeneAmp RNA PCR Kit (Perkin-Elmer, Norwalk, Conn., USA) and amplified (equivalent to $3 \times 10^{3}$ cells) by PCR using AmpliTaq Gold DNA polymerase (Perkin Elmer) and thermo profile as described previously [16]. The numbers of cycles for the PCRs were 28 for GAPDH, and 35 for MCP-1 cDNA. The cycles were selected to allow amplification within the linear range. The gene specific primer sequences and their respective PCR fragment lengths for rat GAPDH, iNOS, and MCP-1 cDNAs are described in a previous study [16]. Primer sequences for human samples are GAPDH-F: 5'-CATGTTCGTCATGGGTGTGA-3', GAPDH-R: 5'-AGTGAGCTTCCCGTTCAGCT-3'; human MCP-1F: 5'-CATAGCAGCCACCTTCATTC3', MCP-1R: 5'-GTGGAGTGAGTGTTCAAGTC-3'; human iNOS-F: 5'-AGAAGTCTCCAGAATCTCTG-3', iNOS-R: 5'-TGGCCAGATGTTCCTCTATT-3'. The ethidium bromide-stained agarose gels were photographed under UV-transillumination using Kodak Digital Science DC40 camera (Kodak, Rochester, N. Y., USA). Abundance of the PCR products of interest was assessed by Biomax 1D Image analysis software (Kodak) and expressed in pixel intensities (O.D.), normalised for the abundance of the GAPDH cDNA signal amplified from the same cDNA sample.

For the in vivo analysis of MCP-1 mRNA in NOD mice, total RNA was extracted from freshly isolated islets from NOD mice (200 islets a condition), which were centrifuged for $5 \mathrm{~min}$ at $930 \mathrm{~g}\left(4^{\circ} \mathrm{C}\right)$ and resuspended in $200 \mu \mathrm{l} \mathrm{PBS}$. Total RNA was extracted using the High Pure RNA Isolation kit (Boehringer Mannheim, Mannheim, Germany). A constant amount of $5 \mu \mathrm{g}$ of target RNA was reverse transcribed with $100 \mathrm{U}$ Superscript II RT (Life Technologies, Gaithersburg, Md., USA) at $42^{\circ} \mathrm{C}$ for $80 \mathrm{~min}$ in the presence of random primers. For determination of in vivo MCP-1 mRNA expression, real time quantitative PCR was carried out in the ABI Prism 7700 Sequence Detector (Perkin Elmer/Applied Biosystems, Foster City, Calif., USA) as described previously [37]. Real time PCR was chosen for these experiments to permit the detection of small changes in mRNA expression, possibly occurring in vivo during progression of insulitis. The PCR amplification reactions $(25 \mu \mathrm{l})$ contained $5 \mu \mathrm{l}$ cDNA sample, $2.5 \mu \mathrm{l} 10 \times$ TaqMan Buffer A, $200 \mu \mathrm{mol} / \mathrm{l}$ dATP, dCTP, dGTP and $400 \mu \mathrm{mol} / \mathrm{l} \mathrm{dUTP}, 3 \mathrm{mmol} / \mathrm{l}$ $\mathrm{MgCl}_{2}, 0.125 \mathrm{U}$ AmpliTaq Gold, $0.25 \mathrm{U}$ AmpErase uracil $N$-glycosylase (UNG), $300 \mathrm{nmol} / \mathrm{l}$ forward primer (5'CTTCTGGGCCTGCTGTTCA-3'), $900 \mathrm{nmol} / \mathrm{l}$ reverse primer (5'-CCAGCCTACTCATTGGGATCA-3') and $200 \mathrm{nmol} / \mathrm{l}$ TaqMan detection probe (5'-CTCAGCCAGATGCAGTTAACGCCCC-3'). For each sample amplification was carried out in triplicate using the following conditions: $2 \mathrm{~min}$ at $50^{\circ} \mathrm{C}$ and $10 \mathrm{~min}$ at $94^{\circ} \mathrm{C}$, followed by 45 two-temperature cycles of $15 \mathrm{~s}$ at $94^{\circ} \mathrm{C}$ and $1 \mathrm{~min}$ at $60^{\circ} \mathrm{C}$. A plasmid clone containing a MCP-1 cDNA PCR fragment was constructed using a pGEM Teasy plasmid vector (Promega, Madison, Wis., USA). Serial dilutions from the resulting plasmid clones containing a known amount of template copy number were used as a standard curve. The MCP-1 cDNA quantity of each cDNA sample was normalised to the housekeeping gene for $\beta$-actin. The measurement of $\beta$-actin mRNA expression by real time PCR was done as described previously [37].
ELISA. Culture media from human islet cells exposed for $72 \mathrm{~h}$ to cytokines or control (no cytokines added) conditions were collected for chemokine measurement by ELISA. MCP-1, MCP-2 and IL-8 were detected in a classical sandwich ELISA. Polyclonal goat anti-human IL-8, polyclonal rabbit anti-human MCP-1 and polyclonal rabbit anti-human MCP-2 were prepared as described previously $[38,39]$ and used for coating in the IL-8, MCP-1 or MCP-2 ELISA, respectively. Monoclonal antibodies against human IL-8, MCP-1 and MCP-2 (R\&D System, Abingdon, UK) were used as capturing antibodies. Natural human IL-8, recombinant human MCP-1 (a kind gift of Dr. J.J. Oppenheim, National Cancer Institute, Frederick, Md., USA) and synthetic MCP-2 were used as standards in the different ELISAs [38, 39]. The detection was carried out with peroxidase-labelled goat anti-mouse $\mathrm{mAb}$ and 3,3',5,5'-tetramethylbenzidine dihydrochloride hydrate (TMB; Aldrich Chem., Milwaukee, Wis., USA). All ELISAs were specific in that they did not show cross-reactivity with a broad panel of chemokines, including MCP-1, MCP-2, MCP3 , eotaxin, RANTES, MIP- $1 \alpha$, MIP-1 $\beta$, LARC, PARC, TARC, GCP-2, ENA-78, GRO- $\alpha$, GRO- $\beta$, GRO- $\gamma$, IL- 8 , SDF-1, IP-10, PF-4, CTAP-III and NAP-2 (data not shown).

Statistical analysis and ethical approval. Values are expressed as means \pm SEM and the statistical differences between the experimental groups were determined by analysis of variance (ANOVA).

All animal experimental procedures were approved and done in accordance with the ethics committee of the Vrije Universiteit Brussel and the Katholieke Universiteit Leuven. Collection of human pancreata for islet isolation was done in accordance with the ethical guidelines of Eurotransplant, the $\beta$ Cell Transplant and the participating European countries.

\section{Results}

IL-1 $\beta$ induced MCP-1 $m R N A$ expression in rat beta cells requires both ERK $1 / 2$ and p38 MAPK pathways. We have previously shown that IL- $1 \beta$ induces maximal MCP-1 mRNA expression in rat beta cells at $6 \mathrm{~h}$, with a reduction in expression at $24 \mathrm{~h} \mathrm{[16].} \mathrm{To} \mathrm{ex-}$ amine whether MAPKs are involved in IL- $1 \beta$-induced MCP-1 mRNA expression, purified rat beta cells were cultured in the presence of IL- $1 \beta$ and MAPK inhibitors for $6 \mathrm{~h}$. The MCP-1 expression was not present in control cells, but IL- $1 \beta$ induced a clear increase in MCP-1 expression (Fig.1), which was inhibited by respectively $20 \%$ and $40 \%$ by p38i and MEKi. When added together, the MAPK blockers caused a nearly $70 \%$ decrease in MCP-1 expression (Fig. 1). Neither IFN- $\gamma$ nor the iNOS blocker LMA modified IL- $1 \beta$-induced iNOS expression in rat beta cells (data not shown).

MCP-1 $m R N A$ expression and protein release by human islet cells. To determine whether cytokines also induce MCP-1 expression in human islet cells, we cultured these cells in the presence of IL- $1 \beta$ or IFN- $\gamma$, or both and evaluated their MCP-1 mRNA content by RT-PCR. As shown in Fig. 2, there was no detectable MCP-1 expression in the control condition (no cyto- 


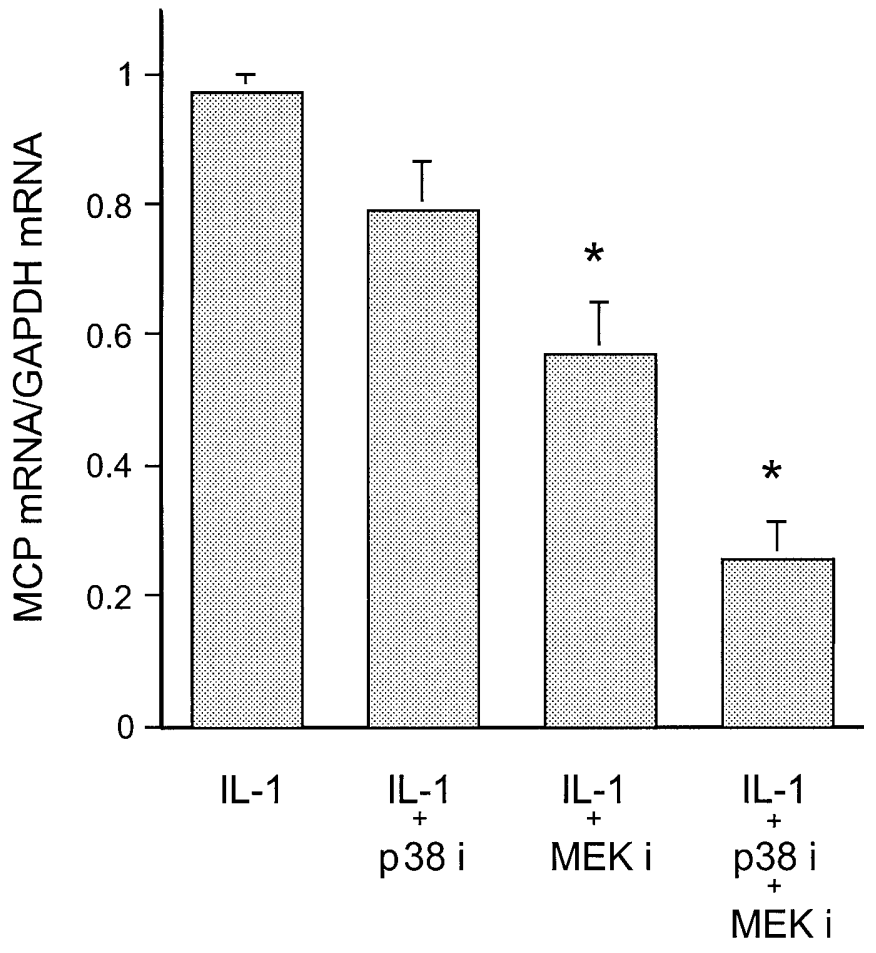

Fig. 1. Effects of MAPK inhibitors on IL- $1 \beta$-induced MCP-1 mRNA expression in rat beta cells. Rat beta cells $\left(5 \times 10^{4}\right.$ cells/well $)$ were exposed to IL-1 $\beta(30 \mathrm{U} / \mathrm{ml})$ or IL- $1 \beta$ plus the MAPK inhibitors p38i (SB203580; $10 \mu \mathrm{mol} / \mathrm{l})$ or MEKi (PD098059; $100 \mu \mathrm{mol} / \mathrm{l}$ ) for $6 \mathrm{~h}$. The cells were then harvested, mRNA extracted and RT-PCR done with the equivalent of $3 \times 10^{3}$ cells. The results are the means \pm SEM of 4 experiments, presented as O.D. corrected per GAPDH expression. $* p<0.001$ vs IL- $1 \beta$ alone

kines added). When cells were exposed to IL- $1 \beta$ for 6 or $24 \mathrm{~h}$ there was a clear induction of MCP-1 expression. IFN- $\gamma$ alone neither increased MCP-1 expression nor potentiated the stimulatory effect of IL- $1 \beta$. The combination of IL- $1 \beta$ and IFN- $\gamma$ has been shown to induce expression of the inducible form of nitric oxide synthase (iNOS) and nitric oxide (NO) production by human islets $[27,28,40]$. We confirmed that IL- $1 \beta$ plus IFN- $\gamma$ but not IL- $1 \beta$ or IFN- $\gamma$ alone induce iNOS expression by human pancreatic islets (Fig.2). To test whether cytokine-induced MCP-1 expression is a NO-mediated phenomenon, human islets were exposed to IL- $1 \beta+$ IFN- $\gamma$ in the presence of $1 \mathrm{mmol} / 1$ L-MA, a treatment which abolishes NO production $[28,29]$. As shown in Fig. 2, L-MA did not prevent cytokine-induced MCP-1 expression. This, and the fact that IL- $1 \beta$ alone induces MCP-1, but not iNOS expression, indicates that cytokine-induced MCP-1 expression is independent of NO production.

To determine whether cytokine-induced MCP-1 expression was indeed associated with MCP-1 protein synthesis and release, medium MCP-1 accumulation was determined following a $72 \mathrm{~h}$ exposure of human islets to different combinations of cytokines (Fig. 3). Only IL- $1 \beta$, but not IFN- $\gamma$ or TNF- $\alpha$, in-
$6 \mathrm{~h}$

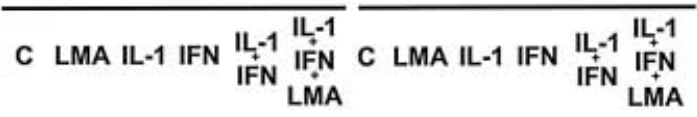

MCP-1

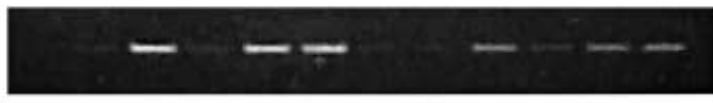

iNOS

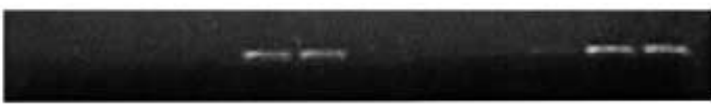

GAPDH

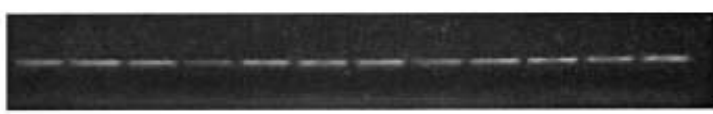

Fig. 2. Effects of cytokines or an iNOS inhibitor or both on MCP-1 and iNOS mRNA expression in human islet cells. Human islet cells $\left(5 \times 10^{4}\right.$ cells/well $)$ were exposed to control conditions (no cytokines added), IL-1 $\beta$ (50 U/ml), IFN- $\gamma$ (1000 U/ $\mathrm{ml})$ and/or the iNOS inhibitor LMA (1 mmol/l) for 6 or $24 \mathrm{~h}$. After these time points the cells were harvested, mRNA extracted and RT-PCR done using MCP-1, iNOS or GAPDH cDNA primers with the equivalent of $3 \times 10^{3}$ cells. The pictures shown are representative for five similar experiments

duced a significant increase in MCP-1 production. In line with the mRNA data, the IL- $1 \beta$ effect was neither potentiated by IFN- $\gamma$ nor by TNF- $\alpha$ (Fig. 3). Moreover, MCP-1 release was not prevented by the iNOS inhibitor L-MA (data not shown).

In parallel to the MCP-1 measurement, we also assessed the production of the $\mathrm{CC}$ chemokine and monocyte chemotattactant MCP-2. There was no detectable medium accumulation of MCP-2, both in controls and following exposure to the different cytokine combinations (data not shown).

Expression of MCP-1 $\mathrm{mRNA}$ in isolated pancreatic islets of NOD mice. Real time RT-PCR analysis of MCP-1 mRNA expression in islets isolated from prediabetic NOD mice was carried out at different time points from 2 to 12 weeks of age. None of the NOD mice used in this study had glucosuria and random blood glucose concentrations at the end of the study did not exceed $125 \mathrm{mg} / \mathrm{dl}$. As an external control, we analysed islets isolated from 4-week-old non-diabetes-prone BALB/c mice.

MCP-1 mRNA was detected as early as 2 weeks of age in both male and female NOD mice islets $(2404 \pm 1029$ and $1853 \pm 934$ MCP-1 cDNA copies $\times 10^{6} / \beta$-actin copies), before histologically insulitis was detected (Fig.4A, B). At 4 and 6 weeks of age, coinciding with progressive islet invasion by inflammatory cells (Fig. 4A, B), there was an increased expression of MCP-1 mRNA, reaching a plateau at 8 weeks of age in both male and female NOD mice (Fig. 5A, B). At 12 weeks of age, more than $80 \%$ of NOD mice developed florid insulitis (Fig. 4A, B). 


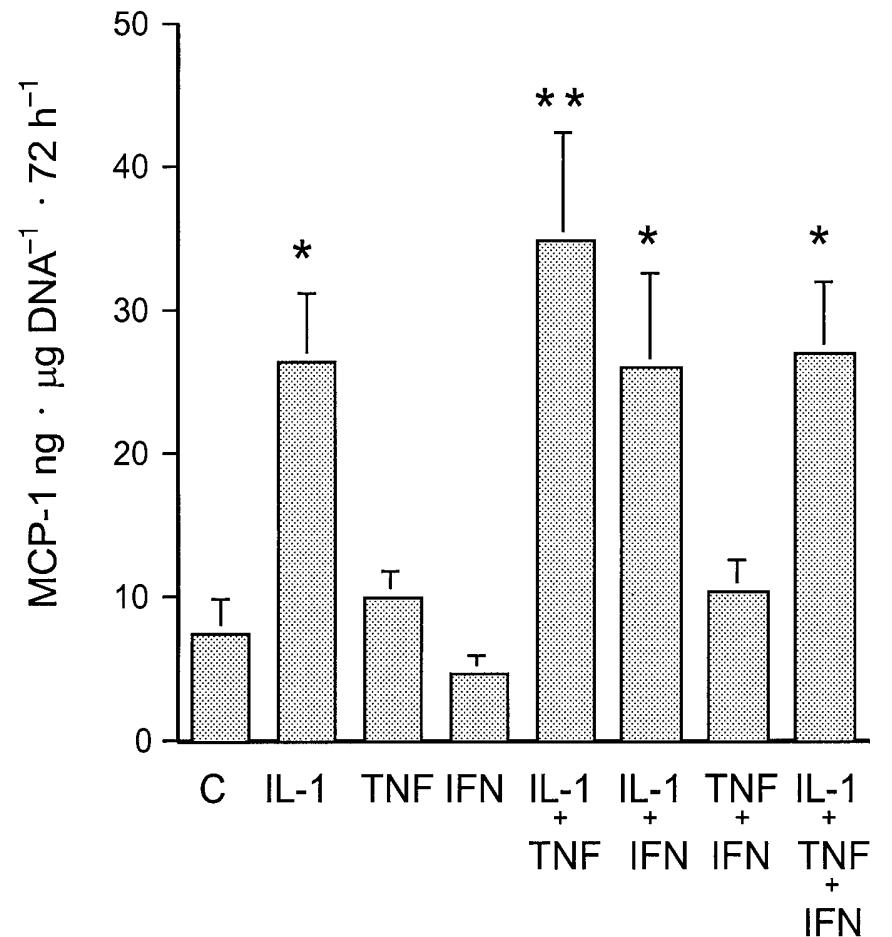

Fig.3. Cytokine-induced MCP protein expression in human islet cells. Human islet cells were cultured for $72 \mathrm{~h}$ in the presence of IL- $1 \beta$, TNF- $\alpha$ or IFN- $\gamma$, alone or in combinations. Medium was then collected for MCP-1 protein measurement by ELISA. Samples were done in duplicate and the data presented are the means \pm SEM of five independent experiments. $* p<0.05$ vs control, $* * p<0.01$ vs control

\section{Discussion}

Chemokines are potent mediators of cell migration and activation. Together with cell adhesion molecules, chemokines have a crucial role in localizing and activating cells in early inflammation [4, 41, 42]. $\mathrm{MCP}-1$ belongs to the $\mathrm{C}-\mathrm{C}$ family of chemokines, attracting monocytes, $\mathrm{T}$ lymphocytes and natural killer cells to the site of inflammation [5, 41, 43]. Transgenic MCP-1 expression under the control of the insulin promoter induces a monocyte-rich insulitis [14] and targeted expression of the MCP-1 gene in murine cardiac muscle leads to increased macrophage infiltration and myocarditis [44]. These results suggest that MCP-1 production in a confined area results in monocyte infiltration [43]. This by itself is not enough to induce tissue destruction [14] but the accumulation of immune competent cells in the close vicinity of the beta cells increases the risk that a second insult, for instances by a viral infection, will trigger destructive insulitis [45].

We have previously observed that the pro-inflammatory cytokine IL- $1 \beta$ induces MCP-1 expression in rat beta cells, with a maximum expression at $6 \mathrm{~h}$ [16]. Induction of MCP- 1 gene expression by IL- $1 \beta$ in human mesangial and endothelial cells requires activa-
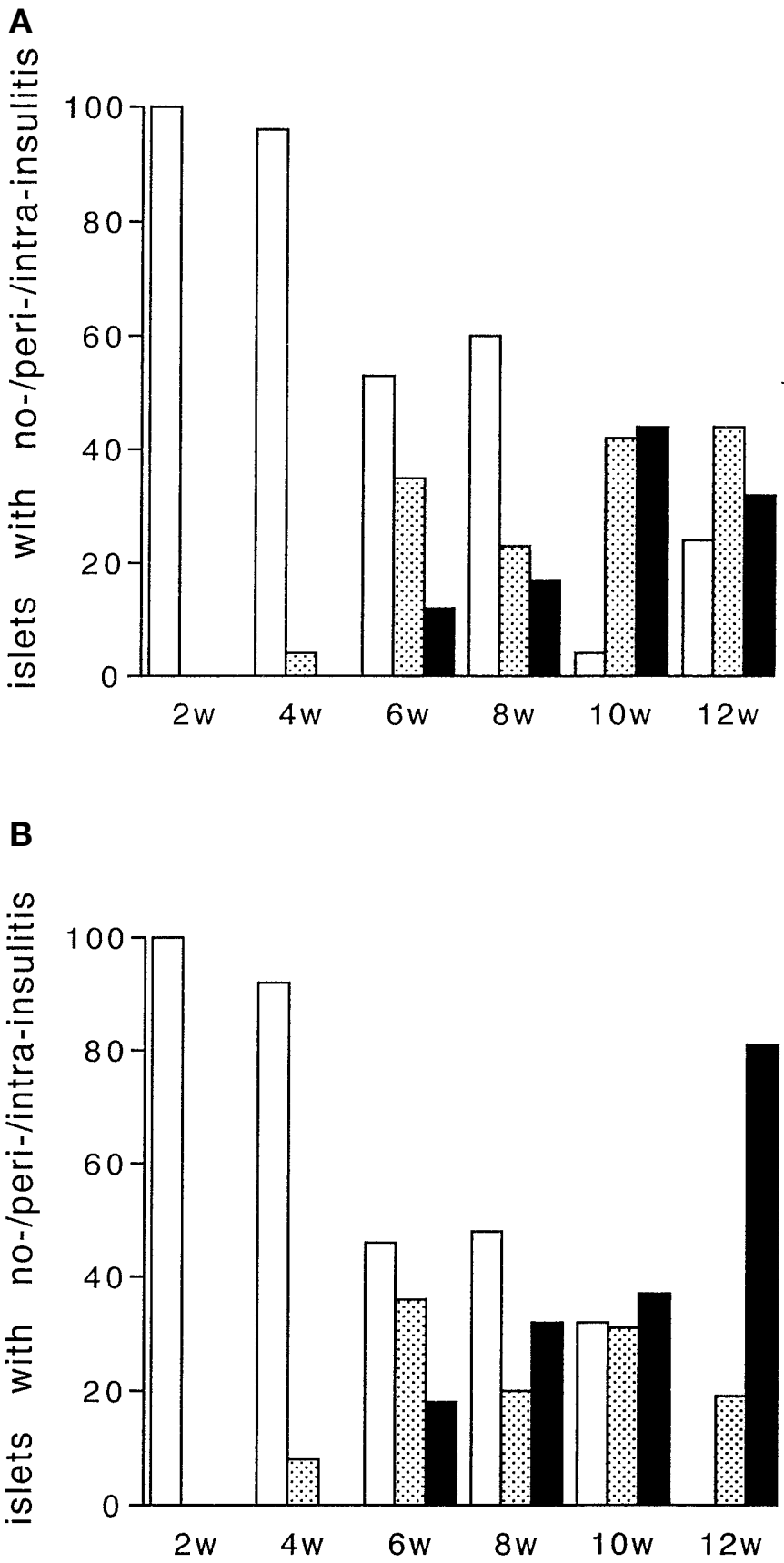

Fig. 4. Analysis of insulitis in pancreases of male (A) and female (B) diabetes-prone NOD mice. The average score of $11-60$ islets per animal $(n=4)$ is shown. Bars indicate the percent of islets with no-insulitis $(\square)$, peri-insulitis $(\square)$ and intra-insulitis $(\square)$. w = week

tion of the MAPK p38 and binding of the transcription factors NF- $x$ B and AP-1 to their specific binding sites at the MCP-1 promoter [41, 46, 47]. The induction of MCP-1 by TNF- $\alpha$ follows a similar signal-transduction pathway [48, 49]. The IL-1 $\beta$ activates the MAPKs p38 and ERK $1 / 2$ in rat islets [22], insulin-producing cells [22] and in FACS-purified rat beta cells [23]. Inhibitors of p38 and ERK1/2, in concentrations similar to the ones used in the present study, decrease cytokine-in- 

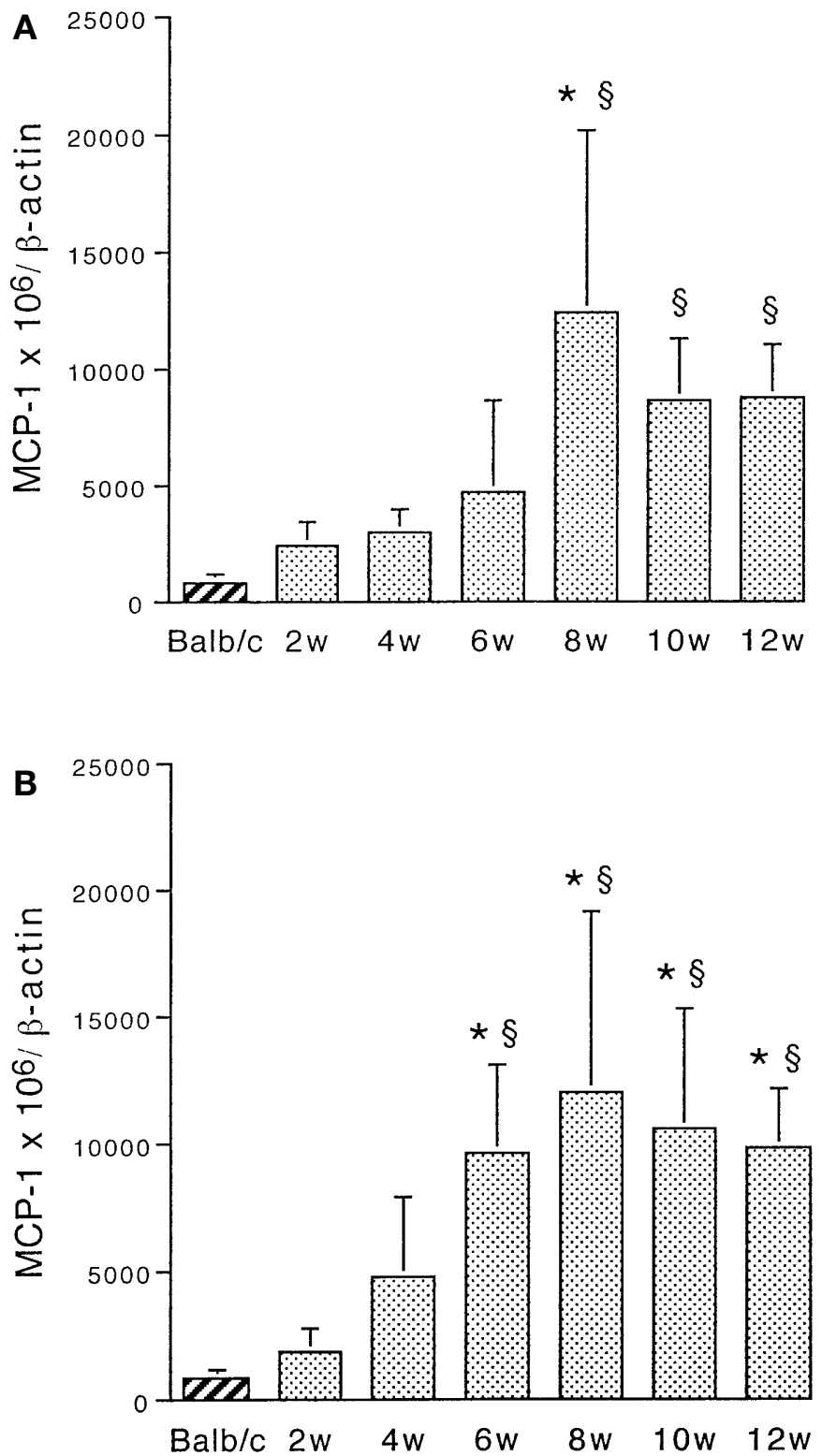

Fig. 5. Time course of MCP-1 mRNA expression in diabetesprone NOD pancreatic islets. mRNA was isolated from islets of male (A) and female (B) NOD mice and analyzed by real time RT-PCR. 4-week-old sex-pooled BALB/c islets were used as non-diabetes-prone controls. The results obtained are means \pm SD for three similar experiments and are expressed as MCP-1 cDNA copies $\times 10^{6} / \beta$-actin copies. $* p<0.05$ vs 2 -week-old NOD islets; $\S p<0.05$ vs 4 -week-old $\mathrm{BALB} / \mathrm{c}$ islets. $\mathrm{w}=$ week

duced iNOS expression and NO production by these cells [22, 23]. Moreover, an ERK1/2 inhibitor, but not a p38 inhibitor, partially counteracted the beta-cell apoptosis induced by IL- $1 \beta+\mathrm{IFN}-\gamma$ [23]. Our present observations, that both $\mathrm{p} 38 \mathrm{i}$ and MEKi induce a partial decrease in MCP-1 mRNA expression and a combination of both inhibitors decreases by nearly $70 \%$ MCP-1 expression, suggest that IL- $1 \beta$-induced MCP1 mRNA expression in rat beta cells requires activation of both $\mathrm{p} 38$ and ERK1/2.

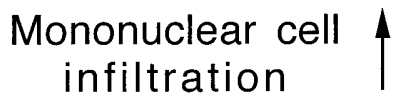

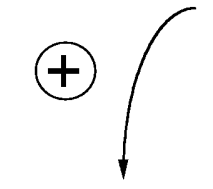

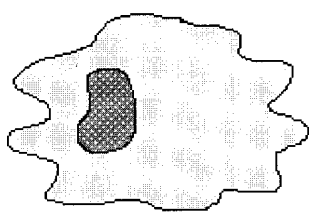

Macrophage
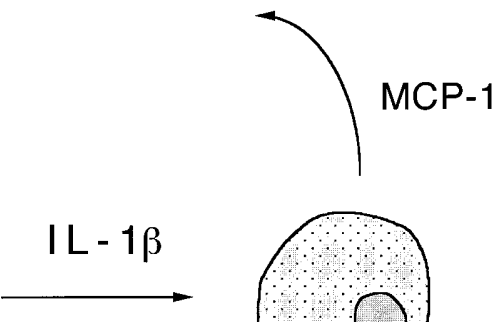

$\beta$-cell

Fig. 6. Proposed role for beta cell MCP-1 expression in the early stages of insulitis. The initial mononuclear islet cell infiltration in experimental autoimmune diabetes is composed mostly of macrophages. These cells are activated and probably release IL- $1 \beta$ in the vicinity of beta cells [reviewed in 15]. Exposure of beta cells to IL- $1 \beta$ leads to MCP- 1 expression and release, further increasing the mononuclear cell infiltration. Conceivably, this "amplification cycle" leads to progressive beta-cell dysfunction and damage

Detection of MCP-1 expression in rat beta cells is not sufficient to permit speculation on a role for the chemokine in human Type I diabetes. Indeed, previous studies by our group have shown that rodent and human islets have different responses following exposure to cytokines or nitric oxide donors [27, 50, 51], indicating the need to validate in human islets findings originally obtained in rodent islets. We observed that human pancreatic islets exposed to IL- $1 \beta$ express MCP-1 mRNA and release increased amounts of MCP-1 protein in the culture medium. The other two pro-inflammatory cytokines tested, namely IFN$\gamma$ and TNF- $\alpha$, neither induced MCP-1 expression by themselves nor potentiated the effects of IL-1 $\beta$. We made similar observations in rat beta cells (data not shown). As a whole, these data suggest that IL- $1 \beta$ mediates induction of MCP-1 production by both human and rat islet cells. This contrasts with observations in other cell types, such as monocytes, fibroblasts and smooth-muscle cells, where IL- $1 \beta$, IFN- $\gamma$ and TNF- $\alpha$ induce MCP-1 production [52]. Another cytokine often co-produced with MCP-1 is MCP-2, which has IFN- $\gamma$ as its main stimulus [52]. The pattern of islet cell response was also different from that described for other cell types, with no detectable MCP-2 production in response to IL- $1 \beta$, IFN- $\gamma$ or TNF- $\alpha$, alone or in combination (present data). The reasons for these intercellular differences are not clear but we have previously observed that islet cells, compared with macrophages, muscle cells, or chondrocytes, express iNOS mRNA in response to different combinations of cytokines or different signal transduction steps or both $[51,53]$. 
To evaluate whether MCP-1 is indeed expressed in pancreatic islets during early insulitis, we then examined MCP-1 mRNA expression in islets isolated from diabetes-prone NOD mice in the prediabetic stage. The period preceding overt diabetes in NOD mice is characterized by an active mononuclear cell infiltration in the islets, beginning at 4 weeks of age $[31,32,54]$. This islet invasion eventually leads to specific destruction of the beta cells and to diabetes in $80-100 \%$ of the female and in $20-40 \%$ of the male NOD mice [31, 32, 54]. We observed that MCP-1 mRNA expression in NOD mouse islets increases in parallel with the progression of insulitis, reaching concentrations severalfold higher than those observed in young, pre-insulitic, NOD mice or in nondiabetes prone mice. The MCP-1 mRNA expression correlates well with MCP-1 protein production and release (present data), suggesting that increased MCP-1 mRNA content in the NOD islets leads to MCP-1 release in the islet microenvironment. Macrophages are probably the first cell type to infiltrate the islets in the early stages of insulitis in NOD mice, followed by $\mathrm{T}$ lymphocytes $[15,55]$. This initial prediabetic phase is associated with the local production of pro-inflammatory cytokines, especially IL- $1 \beta$, IL-6, IFN- $\gamma$ and TNF- $\alpha[15,56]$. This could explain our observations of increased MCP-1 expression in NOD islets. The release of IL-1 and other inflammatory cytokines in the vicinity of the beta cells could lead to both cell damage $[15,51]$ and to MCP-1 production, further amplifying the mononuclear cell infiltrate (Fig. 6). It is noteworthy that female and male NOD mice have similar levels of MCP-1 expression (present data). Although mice from both sexes present mononuclear cell infiltrates around the islets, the prevalence of destructive insulitis and diabetes is much higher in female than in male NOD mice [54]. It has been previously shown that transgenic mice with targeted MCP-1 expression for the beta cells have insulitis but not diabetes [14]. This, together with the present data, suggest that $\mathrm{MCP}-1$ plays a role for the early phase of mononuclear cell homing around the islets but is not sufficient to trigger betacell destruction.

In conclusion, the present data suggest that chemokines, produced by the target cell of the autoimmune attack - i. e. beta cells in Type I diabetes contribute to the local accumulation of immune competent cells. We are presently characterizing the regulation of MCP-1 promoter activity in pancreatic beta cells. The information to be obtained could enable new strategies to be designed to prevent MCP-1 expression and, hopefully, decrease the mononuclear cell invasion in the islets of diabetes-prone experimental animals.

Acknowledgements. We are grateful to Professor D. G. Pipeleers for providing access to human islet cells and to $\mathrm{R}$.
Leeman and the personnel involved in rat islet isolation and beta-cell FACS sorting, for excellent technical assistance. This work was supported by grants from the Juvenile Diabetes Foundation International, the Research Program of the Fund for Scientific Research, Flanders (FWO G.0062.00 and FWO Research Prize Pharmacia \& Upjohn). P. Proost holds a postdoctoral research grant of the FWO.

\section{References}

1. Bach JF (1995) Insulin-dependent diabetes mellitus as a betacell targeted disease of immunoregulation. J Autoimmun 8: 439-463

2. Gepts W (1965) Pathologic anatomy of the pancreas in juvenile diabetes mellitus. Diabetes 14: 619-633

3. Bottazzo GF, Dean BM, McNally JM, MacKay EH, Swift PGF, Gamble DR (1985) In situ characterization of autoimmune phenomena and expression of HLA molecules in the pancreas in diabetic insulitis. N Engl J Med 313: 353-360

4. Baggiolini M, Dewald B, Moser B (1997) Human chemokines: an update. Annu Rev Immunol 15: 675-705

5. Gu L, Tseng SC, Rollins BJ (1999) Monocyte chemoattractant protein-1. Chem Immunol 72: 7-29

6. Yla-Herttuala S, Lipton BA, Rosenfeld ME et al. (1991) Expression of monocyte chemoattractant protein 1 in macrophage-rich areas of human and rabbit atherosclerotic lesions. Proc Natl Acad Sci USA 88: 5252-5256

7. Koch AE, Kunkel SL, Harlow LA et al. (1992) Enhanced production of monocyte chemoattractant protein-1 in rheumatoid arthritis. J Clin Invest 90: 772-779

8. Brown Z, Robson RL, Westwick J (1996) Regulation and expression of chemokines: potential role in glomerulonephritis. J Leukoc Biol 59: 75-80

9. Lioyd CM, Dorf ME, Proudfoot A, Salant DJ, Gutierrez-Ramos JC (1997) Role of MCP-1 and RANTES in inflammation and progression to fibrosis during murine crescentic nephritis. J Leukoc Biol 62: 676-680

10. Boring L, Gosling J, Cleary M, Charo IF (1998) Decreased lesion formation in CCR $2^{-1-}$ mice reveals a role for chemokines in the initiation of atherosclerosis. Nature 394: 894-897

11. Gosling J, Slaymaker S, Gu L et al. (1999) MCP-1 deficiency reduces susceptibility to atherosclerosis in mice that overexpress human apolipoprotein B. J Clin Invest 103: 773-778

12. Flory CM, Jones ML, Warren JS (1993) Pulmonary granuloma formation in the rat is partially dependent on monocyte chemoattractant protein 1. Lab Invest 69: 396-404

13. Rand ML, Warren JS, Mansour MK, Newman W, Ringler DJ (1996) Inhibition of T cell recruitment and cutaneous delayedtype hypersensitivity-induced inflammation with antibodies to monocyte chemoattractant protein-1. Am J Pathol 148: 855-864

14. Grewal IS, Rutledge BJ, Fiorillo JA et al. (1997) Transgenic monocyte chemoattractant protein-1 (MCP-1) in pancreatic islets produces monocyte-rich insulitis without diabetes: abrogation by a second transgene expressing systemic MCP-1. J Immunol 159: 401-408

15. Mandrup-Poulsen T (1996) The role of interleukin-1 in the pathogenesis of IDDM. Diabetologia 39: 1005-1029

16. Chen MC, Schuit F, Eizirik DL (1999) Identification of IL- $1 \beta$ induced messenger RNAs in rat pancreatic beta cells by differential display of messenger RNA. Diabetologia 42: 1199-1203

17. Pipeleers DG, In't Veld P, van de Winkel M, Maes E, Schuit FC, Gepts W (1985) A new in vitro model for the study of pancreatic A and B cells. Endocrinology 117: 806-816

18. Ling Z, Hannaert JC, Pipeleers D (1994) Effect of nutrients, hormones and serum on survival of rat islet $\beta$-cells in culture. Diabetologia 37: 15-21

19. Alessi DR, Cuenda A, Cohen P, Dudley DT, Saltiel AR (1995) PD 098059 is a specific inhibitor of the activation of mitogen- 
activated protein kinase kinase in vitro and in vivo. $\mathrm{J}$ Biol Chem 270: 27489-27494

20. Dudley DT, Pang L, Decker SJ, Bridges AJ, Saltiel AR (1995) A synthetic inhibitor of the mitogen-activated protein kinase cascade. Proc Natl Acad Sci USA 92: 7686-7689

21. Pang L, Sawada T, Decker SJ, Saltiel AR (1995) Inhibition of MAP kinase kinase blocks the differentiation of PC-12 cells induced by nerve growth factor. J Biol Chem 270: 13585-13588

22. Larsen CM, Wadt KA, Juhl LF et al. (1998) Interleukin- $1 \beta$-induced rat pancreatic islet nitric oxide synthesis requires both the p38 and extracellular signal-regulated kinase $1 / 2$ mitogenactivated protein kinases. J Biol Chem 273: 15294-15300

23. Pavlovic D, Andersen NA, Mandrup-Poulsen T, Eizirik DL (2000) Activation of extracellular signal-regulated kinase (ERK)1/2 contributes to cytokine-induced apoptosis in purified rat pancreatic $\beta$ - cells. Eur Cytokine Netw 11: 267-274

24. Pavlovic D, van de Winkel M, van der Auwera B et al. (1997) Effect of interferon- $\gamma$ and glucose on major histocompatibility complex class I and class II expression by pancreatic $\beta$ - and non- $\beta$-cells. J Clin Endocrinol Metab 82: 2329-2336

25. Keymeulen B, Ling Z, Gorus FK et al. (1998) Implantation of standardized $\beta$-cell grafts in a liver segment of IDDM patients: graft and recipients characteristics in two cases of insulin-independence under maintenance immunosuppression for prior kidney graft. Diabetologia 41: 452-459

26. Ling Z, Pipeleers DG (1996) Prolonged exposure of human beta cells to elevated glucose levels results in sustained cellular activation leading to a loss of glucose regulation. J Clin Invest 98: 2805-2812

27. Eizirik DL, Sandler S, Welsh N et al. (1994) Cytokines suppress human islet function irrespective of their effects on nitric oxide generation. J Clin Invest 93: 1968-1974

28. Hostens K, Pavlovic D, Zambre Y et al. (1999) Exposure of human islets to cytokines can result in disproportionately elevated proinsulin release. J Clin Invest 104: 67-72

29. Pavlovic D, Chen MC, Bouwens L, Eizirik DL, Pipeleers D (1999) Contribution of ductal cells to cytokine responses by human pancreatic islets. Diabetes 48: 29-33

30. Casteels K, Waer M, Bouillon R et al. (1998) 1,25-Dihydroxyvitamin $\mathrm{D}_{3}$ restores sensitivity to cyclophosphamideinduced apoptosis in non-obese diabetic (NOD) mice and protects against diabetes. Clin Exp Immunol 112: 181-187

31. Mathieu C, Waer M, Casteels K, Laureys J, Bouillon R (1995) Prevention of type I diabetes in NOD mice by nonhypercalcemic doses of a new structural analog of 1,25-dihydroxyvitamin $\mathrm{D}_{3}, \mathrm{KH} 1060$. Endocrinology 136: 866-872

32. Casteels KM, Mathieu C, Waer M et al. (1998) Prevention of type I diabetes in nonobese diabetic mice by late intervention with nonhypercalcemic analogs of 1,25-dihydroxyvitamin $\mathrm{D}_{3}$ in combination with a short induction course of cyclosporin A. Endocrinology 139: 95-102

33. Casteels K, Waer M, Laureys J et al. (1998) Prevention of autoimmune destruction of syngeneic islet grafts in spontaneously diabetic nonobese diabetic mice by a combination of a vitamin $\mathrm{D}_{3}$ analog and cyclosporine. Transplantation 65: 1225-1232

34. Mathieu C, Laureys J, Sobis H, Vandeputte M, Waer M, Bouillon $R$ (1992) 1,25-Dihydroxyvitamin $D_{3}$ prevents insulitis in NOD mice. Diabetes 41: 1491-1495

35. Mathieu C, Waer M, Laureys J, Rutgeerts O, Bouillon R (1994) Prevention of autoimmune diabetes in NOD mice by 1,25 dihydroxyvitamin $\mathrm{D}_{3}$. Diabetologia 37: 552-558

36. Rothe H, Hausmann A, Casteels K et al. (1999) IL-18 inhibits diabetes development in nonobese diabetic mice by counterregulation of Th1-dependent destructive insulitis. J Immunol 163: $1230-1236$

37. Overbergh L, Valckx D, Waer M, Mathieu C (1999) Quantification of murine cytokine mRNAs using real time quantitative reverse transcriptase PCR. Cytokine 11: 305-312

38. Proost P, Struyf S, Couvreur M et al. (1998) Posttranslational modifications affect the activity of the human monocyte chemotactic proteins MCP-1 and MCP-2: identification of MCP-2 (6-76) as a natural chemokine inhibitor. J Immunol 160: 4034-4041

39. Wuyts A, Govaerts C, Struyf S et al. (1999) Isolation of the CXC chemokines ENA-78, GRO alpha and GRO gamma from tumor cells and leukocytes reveals NH2-terminal heterogeneity. Functional comparison of different natural isoforms. Eur J Biochem 260: 421-429

40. Karlsen AE, Pavlovic D, Nielsen K et al. (2000) Interferon- $\gamma$ induces interleukin-1 converting enzyme expression in pancreatic islets by an interferon regulatory factor-1-dependent mechanism. J Clin Endocrinol Metab 85: 830-836

41. Martin T, Cardarelli PM, Parry GC, Felts KA, Cobb RR (1997) Cytokine induction of monocyte chemoattractant protein-1 gene expression in human endothelial cells depends on the cooperative action of $\mathrm{NF}-\varkappa \mathrm{B}$ and $\mathrm{AP}-1$. Eur $\mathrm{J}$ Immunol 27: 1091-1097

42. Stylianou E, Nie M, Ueda A, Zhao L (1999) c-Rel and p65 trans-activate the monocyte chemoattractant protein-1 gene in interleukin-1 stimulated mesangial cells. Kidney Int 56: 873-882

43. Gu L, Rutledge B, Fiorillo J et al. (1997) In vivo properties of monocyte chemoattractant protein-1. J Leukoc Biol 62: $577-580$

44. Kolattukudy PE, Quach T, Bergese S et al. (1998) Myocarditis induced by targeted expression of the MCP-1 gene in murine cardiac muscle. Am J Pathol 152: 101-111

45. Horwitz MS, Bradley LM, Harbertson J, Krahl T, Lee J, Sarvetnick N (1998) Diabetes induced by Coxsackie virus: initiation by bystander damage and not molecular mimicry. Nat Med 4: 781-785

46. Rovin BH, Dickerson JA, Tan LC, Hebert CA (1995) Activation of nuclear factor- $\varkappa \mathrm{B}$ correlates with MCP-1 expression by human mesangial cells. Kidney Int 48: 1263-1271

47. Rovin BH, Wilmer WA, Danne M, Dickerson JA, Dixon CL, Lu L (1999) The mitogen-activated protein kinase p38 is necesssary for interleukin $1 \beta$-induced monocyte chemoattractant protein 1 expression by human mesangial cells. Cytokine 11: 118-126

48. Goebeler M, Kilian K, Gillitzer R et al. (1999) The MKK6/p38 stress kinase cascade is critical for tumor necrosis factor- $\alpha$-induced expression of monocyte-chemoattractant protein-1 in endothelial cells. Blood 93: 857-865

49. Ping D, Boekhoudt GH, Rogers EM, Boss JM (1999) Nuclear factor- $\varkappa \mathrm{B}$ p 65 mediates the assembly and activation of the TNF-responsive element of the murine monocyte chemoattractant-1 gene. J Immunol 162: 727-734

50. Eizirik DL, Pipeleers DG, Ling Z, Welsh N, Hellerström C, Andersson A (1994) Major species differences between humans and rodents in the susceptibility to pancreatic $\beta$-cell injury. Proc Natl Acad Sci USA 91: 9253-9256

51. Eizirik DL, Flodström M, Karlsen AE, Welsh N (1996) The harmony of the spheres: inducible nitric oxide synthase and related genes in pancreatic beta cells. Diabetologia 39: 875-890

52. Proost P, Wuyts A, Opdenakker G, Van Damme J 1998. Monocyte chemotactic proteins 1, 2 and 3. In Cytokines. A. Mire-Sluis, and R. Thorpe, editors. London: Academic Press. 489-506.

53. Pavlovic D, Chen MC, Gysemans CA, Mathieu C, Eizirik DL (1999) The role of interferon regulatory factor-1 in cytokine-induced mRNA expression and cell death in murine pancreatic $\beta$-cells. Eur Cytokine Netw 10: 403-412

54. Tochino Y (1987) The NOD mouse as a model of type I diabetes. Crit Rev Immunol 8: 49-81

55. Lee KU, Amano K, Yoon JW (1988) Evidence for initial involvement of macrophage in development of insulitis in NOD mice. Diabetes 37: 989-991

56. Pilstrom B, Bjork L, Böhme J (1997) Monokine-producing cells predominate in the recruitment phase of NOD insulitis while cells producing Th1-type cytokines characterize the effector phase. J Autoimmun 10: 147-155 